\title{
Bridging the Gap between Brazilian Startups and Business Processes - Process Thinking's Initial Exploratory Case Study
}

\author{
Andréa Magalhães Magdaleno ${ }^{1,2}$, Priscila Engiel ${ }^{2,3}$, Rafael Lage Tavares ${ }^{2,4}$, Pedro \\ Silveira Pisa ${ }^{5}$, Renata Mendes de Araujo ${ }^{6}$ \\ ${ }^{1}$ UFF - Fluminense Federal University, IC - Computing Institute \\ Zip 24210-346 - Niterói - RJ - Brazil \\ ${ }^{2}$ dheka - Consultoria em TI \& Gestão \\ www.dheka.com.br - Rio de Janeiro - RJ - Brazil \\ ${ }^{3}$ Programa de Pós-Graduação em Informática PUC-Rio, \\ Rio de Janeiro - RJ - Brazil \\ ${ }^{4}$ UFRJ - Federal University of Rio de Janeiro - Graduate Program in Informatics, Rio \\ de Janeiro - RJ - Brazil \\ ${ }^{5}$ Kendoo Solutions - Serviços em Tecnologia da Informação \\ www.kendoo.com.br - Rio de Janeiro - RJ - Brazil \\ ${ }^{6}$ Graduate Program in Information Systems (PPGI) - UNIRIO, Rio de Janeiro - RJ - \\ Brazil

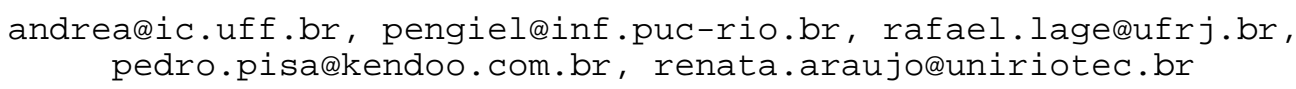

\begin{abstract}
Startup is a new business segment that has been growing up in the last years. These companies have an innovative spirit and are usually searching for new solutions to real problems that can be transformed into scalable businesses. The majority of these companies are not aware of their processes and how the company need to be organized. For this kind of companies, we propose Process Thinking, an innovative approach that makes the business process management viable in the daily lives of startups. This paper presents the Process Thinking framework, which prescribes 10 main processes that a startup needs and a utility belt to help the startup to organize their processes. We illustrate this proposal through an exploratory case study with a real IT startup company that used a 5-step methodology in an immediate implementation of proposed processes and artifacts. The results indicate a positive impact in the short and medium term strategies and management of the startup. However, these results cannot be generalized to other startups and should be received with caution, since this is an initial exploratory study limited to a single company.
\end{abstract}

MAGDALENO, A. M.; ENGIEL, P.; TAVARES, R.; PISA, P. S.; ARAUJO, R. M.

Bridging the Gap between Brazilian Startups and Business Processes - Process Thinking's Initial Exploratory Case Study

iSys | Revista Brasileira de Sistemas de Informação, Rio de Janeiro, vol. 10, No. 1, pp. 19-38, 2017 


\section{Introduction}

According to data of SEBRAE (a Brazilian public service to support micro and small companies), together, the approximately 9 million micro and small enterprises represent $27 \%$ of Brazilian GDP (Gross domestic product) ${ }^{1}$, a result that has been growing in recent years. Micro and small enterprises account for more than 50\% of Brazil's formal jobs $^{2}$. This data indicate the importance of smaller enterprises, as they are decisive for the national economy.

However, approximately $25 \%$ of micro, small, and medium enterprises (MSMEs) go bankrupt in their first two years of operation. Additionally, according to the data from the Brazilian Association of Startups (AB Startups) ${ }^{3}$, 90\% startups break.

It is necessary to reduce the mortality rate of these early-stage companies. Among the most common problems that threatens the survival of these companies ${ }^{4}$ are the lack of: knowledge about the market segment; brand identity; planning; financial control; and lack or disorganized management. Without the properly management, the entrepreneurs can face the challenge of bankruptcy.

These results can be partially explained by the increasingly competitive and turbulent market in which many of these companies need to operate. They need to answer quickly to new market demands, opportunities, and threats. Thus, it is important to organize their management to achieve agility in their processes and meet customer demands, providing fast and quality products and personalized services.

Processes run in all companies, regardless of their size or business sector, even if they are not clear, visible, documented or organized. The problem is that usually the startups do not have the habit of reflect about their processes [Maschka, 2014]. The current scenario of competitiveness, business opportunities and technical challenges consumes these companies' resources and they often fail to plan or organize their processes.

On the other hand, traditional Business Process Management (BPM) approaches suggest performing different activities concerning all the phases of the BPM cycle (design, modeling, simulation, execution, monitoring and improvement) [Dumas et al., 2013; Engiel, 2014; Weske, 2012], making BPM projects expensive and time consuming. The current reality of startups demands more agile BPM projects as managers seek quick results and market demands new business models. Thus, the

\footnotetext{
${ }^{1}$ Sebrae (In Portuguese): https://www.sebrae.com.br/sites/PortalSebrae/ufs/mt/noticias/micro-e-pequenasempresas-geram-27-do-pib-do-brasil,ad0fc70646467410VgnVCM2000003c74010aRCRD
}

2 Sebrae (In Portuguese):

https://www.sebrae.com.br/Sebrae/Portal\%20Sebrae/Anexos/Sobrevivencia_das_empresas_no_Brasil_20 11.pdf

Data from AB Startups (In Portuguese): http://www.tirio.org.br/TI-RIONoticias/Clipping/Negocios/Startups\%3A-um-jeito-inovador-de-empreender\%2C-mas-com-muitasdificuldades-no-caminho-32540.html

4 Computer World (In Portuguese): http://computerworld.com.br/negocios/2014/02/17/falta-de-gestaoprofissional-ameaca-sobrevivencia-de-pmes/

MAGDALENO, A. M.; ENGIEL, P ; TAVARES, R ; PISA, P. S ; ARAUJO, R. M

Bridging the Gap between Brazilian Startups and Business Processes - Process Thinking's Initial Exploratory Case Study

isys | Revista Brasileira de Sistemas de Informação, Rio de Janeiro, vol. 10, No. 1, pp. 19-38, 2017 
traditional BPM approaches begin to be revised to promptly deliver results and products. Therefore, idea of Agile BPM arose [Magdaleno, 2014a; Magdaleno, 2014b; Thiemich and Puhlmann, 2013; Weibach et al., 2016] to make BPM approaches more dynamic and iterative. Agile BPM inspired the idea of Process Thinking, which differs by focusing specifically on startups environments with a framework of solutions.

The Process Thinking 5 framework proposed in this paper aims to promote the analysis and rethinking of startups' business processes in a playful, agile, and innovative way. The main goal is to adapt the processes management activities to the reality of startups, making it an instrument that is part of the day-by-day of these companies. To achieve this goal, Process Thinking describes 10 processes that are considered fundamental to startup's management. Each process is represented through a process model. It also provides a "utility belt" that works as a box of different types (including documents, videos, tools, and links) of instruments to help entrepreneurs to adopt the processes in their startups.

In order to evaluate the Process Thinking framework in a real context, an exploratory study was planned and conducted with a young IT startup. The study applied Process Thinking solutions, including Process Map (a proposal of 10 main process common for any startup), 3 process flows and the utility belt to an immediately implementation of proposed processes and artifacts. The results indicate a positive impact in the short and medium term strategies and management of the startup. The study also highlights that typical BPM notations, such as BPMN [OMG, 2009], can be too complex for non-technical users, which miss a simplified representation of their processes.

The remainder of this paper is structured as follows. In Section 2, background information on processes and the specific startup context is provided. Section 3 summarizes the Process Thinking framework and its 10 processes. Section 4 is dedicated to the exploratory case study that evaluated the Process Thinking framework in the context of a real startup. Section 5 discusses related work. Finally, Section 6 concludes the paper and indicates opportunities for future work.

\section{Processes and Startups Background}

Business Process Management (BPM) [Dumas et al., 2013; Weske, 2012] is a way for companies to organize their work and resources (human, physical, technological, informational, etc.) to achieve their goals and to comply with their customers' demands. A process transforms or manipulates its inputs to produce goods or provide services that meet demands generated by customers. A process model explains how the organization works and how the activities need to be done.

Processes are inherent to companies' day-to-day operations, also when they are not explicitly represented or formalized. Although, many companies do not know how to plan or manage their business processes. If a process is not analyzed, it may be executed in a chaotic and uncontrolled way. In any company, there is a common set of

\footnotetext{
${ }^{5}$ Site Process Thinking (In Portuguese): http://www.processthinking.com.br

MAGDALENO, A. M.; ENGIEL, P.; TAVARES, R.; PISA, P. S.; ARAUJO, R. M.

Bridging the Gap between Brazilian Startups and Business Processes - Process Thinking's Initial Exploratory Case Study

isys | Revista Brasileira de Sistemas de Informação, Rio de Janeiro, vol. 10, No. 1, pp. 19-38, 2017
} 
core processes that must exist for the organization to function properly. Without the properly processes management, the entrepreneurs can face problems that can lead a company to bankruptcy.

However, the notion of processes is generally associated with large enterprises, bureaucracy and inefficiency. Therefore, the traditional BPM approaches of [Baldam et al., 2009; Elzinga et al., 1995; Paim, 2009; Sharp and McDermott, 2001] do not suit well in all business environments, especially highly dynamic ones. Usually, it requires a lot of effort to model and analyze a process. The root causes of the problem are the long cycles of process elicitation and modeling, as well as the lack of partial deliverables. Depending on a project's complexity and the number of professionals involved, multiple meetings may be necessary to gather requirements and model processes. This can result in a high cost. This motivates the impression that BPM is a luxury restricted only to the big companies. In this scenario, the traditional BPM approaches need to be adapted to the context of startups, in order to deliver the results and products as expected.

In Brazil, the national classification of the company sizes ${ }^{6}$ considers that a micro business has an annual gross revenue of up to $\mathrm{R} \$ 360.000$ and a small business has an annual gross revenue of up to $\mathrm{R} \$ 3.6$ million. Inside this universe of micro or small companies, the startups have particular characteristics and deserves special attention.

Startups are companies that explore an unknown or innovative business model [Blank and Dorf, 2014]. They are concerned with the development of new business ideas [Damodaran, 2012]. Their focus is to solve complex problems or explore new business markets using innovative ideas. They have promising projects with low upfront costs and are highly scalable, i.e., they have an expectation of very large growth when they succeed [SEBRAE-MG, 2014]. Being young and launching an idea in the market, they have high risks involved in the business.

Startups are always trying to do the best with few resources. Normally, they are highly occupied and do not have time to reflect on their processes [Maschka, 2014]. They focus on the technological aspect of the innovative product creation and become unaware of the other internal or external variables affecting the company that they are building. In addition, startups operate in a continuously changing environment, where product, business target, roles and professionals are frequently changing.

Typically, startups do not have time and money to invest in BPM. Still, they need to think about their processes in an objective manner and require guidance to implement the processes in their day life, with little effort. This represents the goal of Process Thinking, which we present in the next section.

\section{Process Thinking}

Process Thinking proposal is to analyze and rethink business processes in an innovative, agile and ludic way. Process Thinking main purpose is to bring BPM to the reality of startups processes. Process Thinking framework was inspired in the ideas of Agile BPM

\footnotetext{
${ }^{6}$ According to Brazilian Internal Revenue: http://www.receita.fazenda.gov.br

MAGDALENO, A. M.; ENGIEL, P.; TAVARES, R.; PISA, P. S.; ARAUJO, R. M.

Bridging the Gap between Brazilian Startups and Business Processes - Process Thinking's Initial Exploratory Case Study

isys | Revista Brasileira de Sistemas de Informação, Rio de Janeiro, vol. 10, No. 1, pp. 19-38, 2017
} 
[Magdaleno, 2014a; Magdaleno, 2014b; Thiemich and Puhlmann, 2013] and with the principles of Service Design Thinking ${ }^{7}$ [Stickdorn and Schneider, 2012].

Process Thinking comprises the following set of solutions: (i) Process Map with 10 main processes common for any startup (see Section 3.1); (ii) Each main process is decomposed and the specific processes are represented through a process model (see Section 3.2); (iii) It also provides an "utility belt" (see Section 3.3) with a set of documents templates, examples, helpful tools to support those processes, useful references and links, and training to help entrepreneurs to adopt the processes and make them real in their startups.

\subsection{Process Map}

As part of Process Thinking framework, we propose a process map to help the startups to understand and organize their main processes. The proposed processes are commonly found in different organizations, but vary in complexity from one to another. In Process Thinking, these processes were previously defined and modeled in accordance with the specific context of startups. Therefore, they can be easily selected and implemented by startups.

This process map (Figure 1) is composed by three types of business processes: i) Management processes, processes that govern the operation of a company; ii) Core processes, processes that constitute the primary business of an organization, mainly related with the creation and transformation of goods and services; iii) Support processes, which support the core processes execution. The main processes are decomposed in processes, as detailed below.

\section{PROCESS MAP}

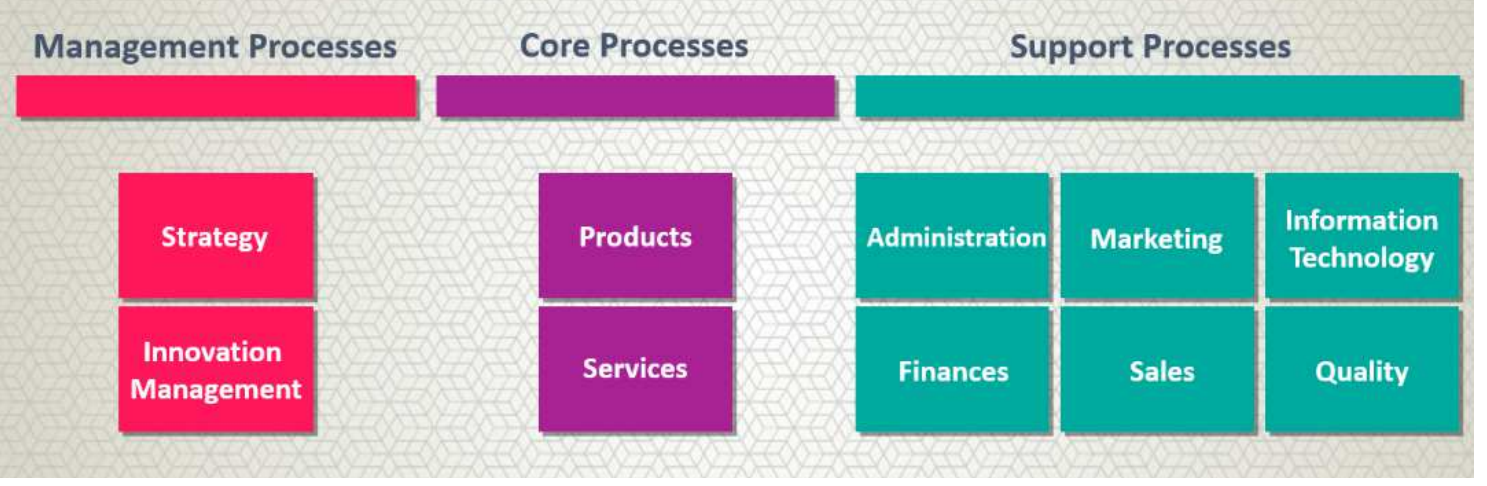

Figure 1 - Process Thinking's Map

-Strategy: Guides a startup to look inside and defines its main goals, the reason for their existence and a strategic path to their businesses.

\footnotetext{
${ }^{7}$ Service Design Thinking: http://thisisservicedesignthinking.com

MAGDALENO, A. M.; ENGIEL, P.; TAVARES, R.; PISA, P. S.; ARAUJO, R. M.

Bridging the Gap between Brazilian Startups and Business Processes - Process Thinking's Initial Exploratory Case Study

isys | Revista Brasileira de Sistemas de Informação, Rio de Janeiro, vol. 10, No. 1, pp. 19-38, 2017
} 
Processes: Manage Business Plan; Manage Strategy Plan.

-Innovation Management: Innovation is important to keep a startup competitive. Innovation management allows a startup to respond to external or internal opportunities, and use its creativity to introduce new ideas, processes, products and ways to solve common problems.

Processes: Problem Understand; Ideas Search; Ideas Select; Ideas Implement; Learning.

-Products: Comprises all product development until delivery to customer. It is important not to think only in product but in the process to develop this product with high quality and in a quick way.

Processes: Product Development; Product Delivery; Support.

-Services: Follows the same idea of the Products. It is necessary to plan the main characteristics of the service to be provided and define how it will be launched quickly and with good quality.

Processes: Service Development; Service Execution.

-Administration: Break down the operation of a startup. Allows entrepreneurs to obtain a clear picture of day-to-day operations. Administration can refer to the operational performance of routine office tasks, usually internally oriented as processes to hire or fire employers, control inventory, manage general services, such as cleaning or warehousing, and to certify that a startup is operating according to the laws.

Processes: Human Resources; Law Advisory; Maintain inventory; Maintain general services.

-Marketing: It is very important to make a startup, their products and services known by the public, becoming a brand. Creating meaningful messages through words, ideas and images. Marketing is also responsible for ensuring that messages and images are delivered consistently.

Processes: Marketing Plan; Brand Management; Market Analysis; Content Management; Advertising Management; Social Medias Management; Endomarketing; Main Press Advertising.

-Information Technology: Nowadays all companies are supported by information and communication technologies. Startups need infrastructure and applications to support their operations.

Processes: Infrastructure Management; Applications Management; Site Maintenance.

-Finances: Responsible for startup's financial assets. It needs to ensuring profits and smart use of capital making internal investments and managing cash flow. Is responsible for all bills, taxes and contracts that need to be paid or received.

Processes: Budget Management; Maintain cash flow and payments; Funding Management; Accounting Management.

MAGDALENO, A. M.; ENGIEL, P.; TAVARES, R.; PISA, P. S.; ARAUJO, R. M.

Bridging the Gap between Brazilian Startups and Business Processes - Process Thinking's Initial

Exploratory Case Study

isys | Revista Brasileira de Sistemas de Informação, Rio de Janeiro, vol. 10, No. 1, pp. 19-38, 2017 
-Sales: Responsible for ensure that products and services reach customers at the lowest possible cost. It enables new business, through prospecting new clients, attending to events to improve business network, know competitors, suppliers, manage contracts and customer relationships, ensuring customer satisfaction.

Processes: Customers Prospect; Events Participation; Contact Network Management; Partnership Management; Customer Relationship Management.

-Quality: Responsible for ensure that a product or service is consistent and have high quality. It comprehends the creation and maintenance of quality standards, as well as the application of a verification process, which uses the previously defined quality standards.

Processes: Establish Quality Standards; Quality Verification.

\subsection{Process Flow}

Each main process of the process map is properly modeled in Process Thinking framework. Considering "Strategy" main process as an example, one can understand (through Figure 2) that it is composed by "Manage Business plan" and "Manage Strategy plan" processes.

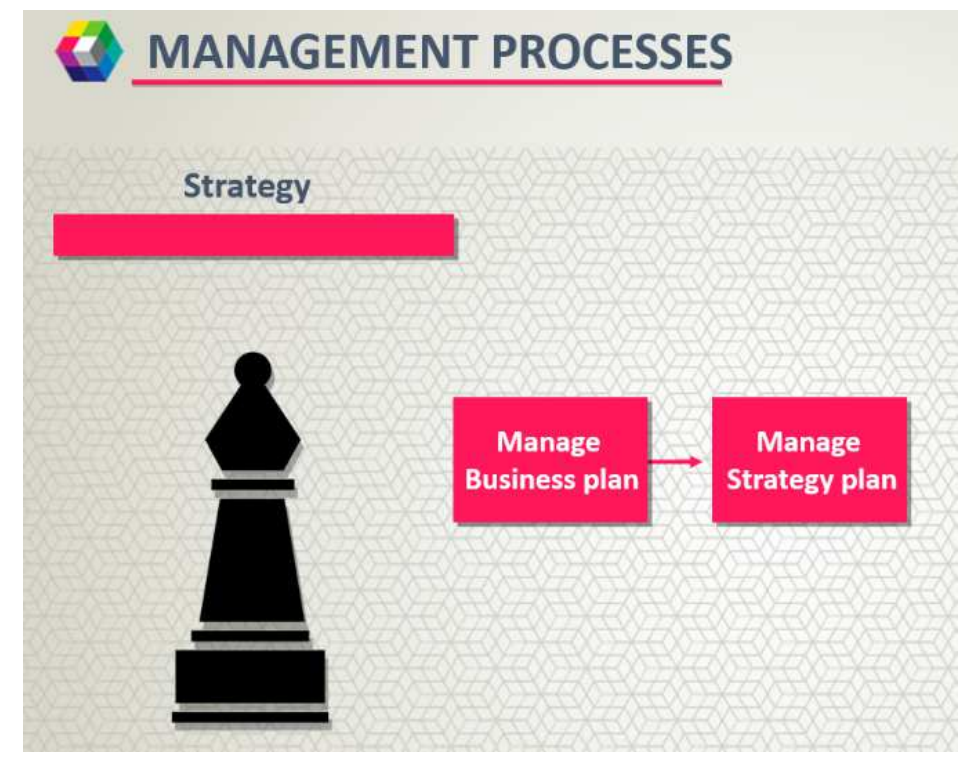

Figure 2 - Strategy main process

Each process is then detailed through a process flow, which presents begin, end, actors, activities, gateways, and artifacts. For instance, in "Manage Business plan" (Figure 3 ) the partner is responsible for bimonthly analyze the business model (canvas model) and the business plan and verify if updates are required. If changes are made, it should also be checked if the strategic plan or portfolio of products and services were not affected and need to be modified.

MAGDALENO, A. M.; ENGIEL, P.; TAVARES, R.; PISA, P. S.; ARAUJO, R. M.

Bridging the Gap between Brazilian Startups and Business Processes - Process Thinking's Initial Exploratory Case Study

isys | Revista Brasileira de Sistemas de Informação, Rio de Janeiro, vol. 10, No. 1, pp. 19-38, 2017 


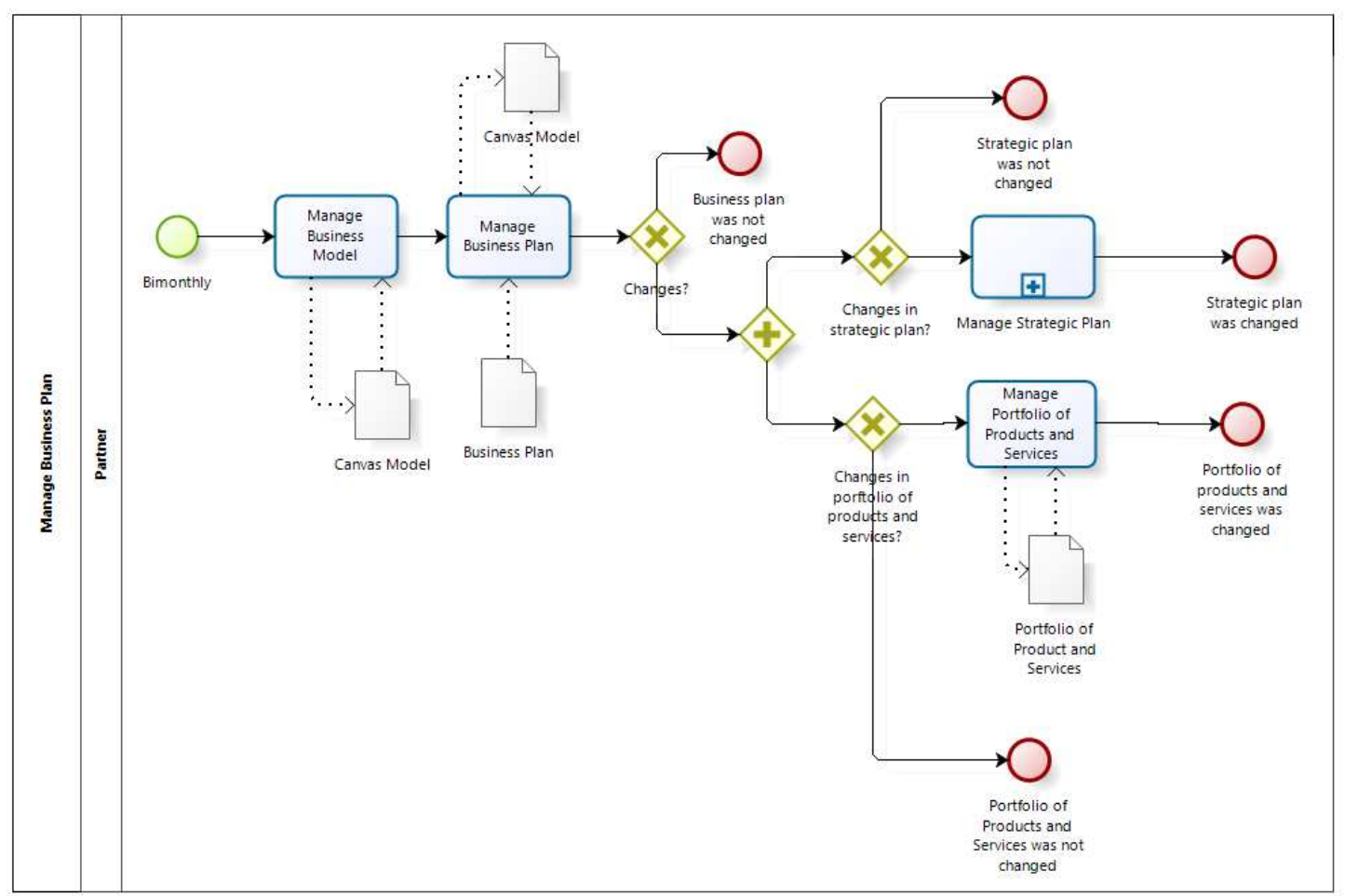

Figure 3 - Manage Business Plan Process Flow

\subsection{Utility Belt}

For each process, we proposed a utility belt to help a company to apply it in the daily activities with the proper support. The utility belt is tailored for each process. Each process has its own set of documents that needs to be built and maintained during process execution. The utility belt (Figure 4) provides, for each process, a set of templates, apps, guides, examples, books, videos, and courses to help users apply it when needed. Templates, guides, and examples are perfect for a fast development of a first version, while books, videos, and courses are better when a user needs to have a deeper understanding about a specific document or concept related to it. For example, for the Canvas model, which a startup should build as one of the resources needed to Manage Business Plan, the utility belt provides two different types of template, four apps, two guides, and an example, for a quick start in building the Canvas model. Besides that, for further study, there is a book, a video, and a full course to help a user in understanding what is a Canvas model, its purpose and how to build it.

The goal of this framework of solutions is to help a startup to implement one or more processes. Startups need to analyze the proposed processes according to their reality, sometimes adapt some parts of it and choose the instruments to guide process execution. They can benefit from reuse of the already established processes that avoid the work of process creation from scratch as in traditional BPM approaches.

MAGDALENO, A. M.; ENGIEL, P.; TAVARES, R.; PISA, P. S.; ARAUJO, R. M.

Bridging the Gap between Brazilian Startups and Business Processes - Process Thinking's Initial Exploratory Case Study

isys | Revista Brasileira de Sistemas de Informação, Rio de Janeiro, vol. 10, No. 1, pp. 19-38, 2017 


\section{dheka Utility Belt}

\begin{tabular}{|c|c|c|c|c|c|c|}
\hline & & Canvas & & Business Plan & & Strategic Plan \\
\hline \multirow{2}{*}{ Template } & $c=$ & Sebrae & $\angle x$ & Sebrae & \multirow{2}{*}{ (4) } & \multirow{2}{*}{ Template Dheka } \\
\hline & - & Endeavor & 02 & UFPE & & \\
\hline \multirow{4}{*}{ Apps } & $\nexists$ & Strategizer app & \multirow{4}{*}{$\Rightarrow$} & \multirow{4}{*}{ Sebrae } & & \\
\hline & 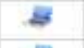 & Sebrae Canvas (iOS) & & & & \\
\hline & $B$ & BMFiddle & & & & \\
\hline & 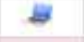 & Canvanizer & & & & \\
\hline \multirow{2}{*}{ Guides } & - & Sebrae & $\overline{-}$ & Sebrae & $\not z$ & Luz \\
\hline & - & Oficina Da Net & - & Produzindo.net & $z$ & Sebrae \\
\hline \multirow{4}{*}{ Examples } & \multirow{4}{*}{$x$} & \multirow{4}{*}{ Dheka } & \multirow{2}{*}{$\pi$} & \multirow{2}{*}{ Bazar } & (1) & Dheka \\
\hline & & & & & ஜี & Sebrae ES \\
\hline & & & \multirow[t]{2}{*}{ (1) } & \multirow{2}{*}{ Produzindo.net } & 2 & Sebrae \\
\hline & & & & & I & Rio de Janeiro's Town Hall \\
\hline \multirow{2}{*}{$\begin{array}{l}\text { Books / } \\
\text { E-books }\end{array}$} & \multirow{2}{*}{ E } & \multirow{2}{*}{$\begin{array}{l}\text { Business Model Generation. } \\
\text { Innovation in business } \\
\text { models (payed content) }\end{array}$} & E & $\begin{array}{l}\text { Business Plan: Your definitive } \\
\text { guide (payed content) }\end{array}$ & E & Endeavor \\
\hline & & & e & $\begin{array}{l}\text { Business Plan - Practical } \\
\text { Examples (payed content) }\end{array}$ & 를 & $\begin{array}{l}\text { FGV Editorial (payed } \\
\text { content) }\end{array}$ \\
\hline \multirow{2}{*}{ Videos } & \multirow{2}{*}{ - } & \multirow{2}{*}{ Sebrae Business Plan } & 0 & Sebrae & $\boldsymbol{0}$ & Endeavor \\
\hline & & & $\mathbf{0}$ & Luz & a & Luz \\
\hline Courses & 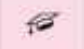 & FazInova & F & Sebrae & fo & Endeavor \\
\hline
\end{tabular}

Figure 4 - Process Thinking Utility Belt

\section{Exploratory Case Study}

This exploratory case study has the following goal and scope, defined based on GQM (Goal, Question, Metric) methodology [Basili et al., 1994]:

Analyze Process Thinking solutions

With the purpose of characterizing

With respect to applicability

From the point of view of entrepreneurs

In the context of startups

This exploratory case study intends to answer the following research question:

\section{RQ: The Process Thinking framework can be applicable in the context of a real startup?}

To answer this RQ we used a real company to evaluate both the process map and the utility belt proposed. The startup We Sense $^{8}$ was a first customer interested in Process Thinking framework of solutions. It is an IT company, with less than one year

\footnotetext{
${ }^{8}$ Site: http://www.wesense.com.br

MAGDALENO, A. M.; ENGIEL, P.; TAVARES, R.; PISA, P. S.; ARAUJO, R. M.

Bridging the Gap between Brazilian Startups and Business Processes - Process Thinking's Initial Exploratory Case Study

iSys | Revista Brasileira de Sistemas de Informação, Rio de Janeiro, vol. 10, No. 1, pp. 19-38, 2017
} 
of existence and with a portfolio of previous performed projects. It is focused on user experience and dedicated to co-create experiences and products capable of instigating emotions through interactive installations developed using technologies such as electronics and movement sensors, image processing, interaction design, and computing. We Sense develops projects involving interfaces, interactions, and people. It is composed by only one dedicated entrepreneur and eventual collaborators. We Sense was receiving its first investment through the government program of Startup Rio ${ }^{9}$ in 2013. Because of all growth opportunities, the business entrepreneur realized that he needed help to structure the company and organize its processes.

The work started with a presentation to startup owner of Process Thinking processes (Figure 1) and the work methodology used in the study. This methodology comprises five steps (Figure 5): i) Diagnosis - understand startups needs through a SWOT analysis; ii) Scope - select from Process Thinking main processes the ones to focus considering the diagnosis and needs previously identified; iii) AS-IS - an agile understanding of the current situation of the selected processes to adapt the proposed process to the startup reality, maintain company good practices, avoid resistance, and suggest future improvements; iv) TO-BE - adapt and model the proposed process to achieve better results and select which documents to use from the utility belt; v) Implementation - use the new processes with the utility belt, including documents templates or tools as a guide. Each step of this methodology produces its respective artifacts as presented in Figure 5.

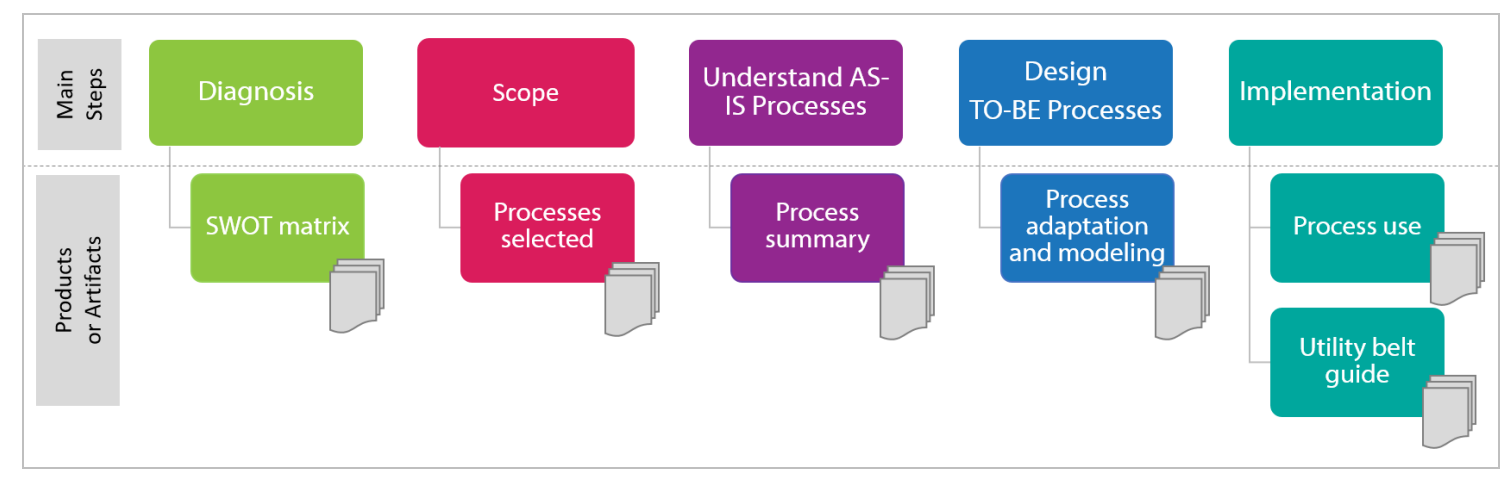

Figure 5 - Process Thinking Work Methodology

The study was conducted over 2 months with the participation of the business entrepreneur. Throughout the work, weekly meetings (with 2 hours of duration) were performed involving the entrepreneur and two researchers. In total, it took 60 hours of work, including both meetings and artifacts preparation.

The meetings were a moment of very rich discussions about the processes. The entrepreneur can present his experiences and tell his problems regarding company management. Researchers understand business differentials and contribute with suggestions for improvements in processes, documents and tools to leverage the results.

\footnotetext{
${ }^{9}$ Startup Rio: http://www.startuprio.org/

MAGDALENO, A. M.; ENGIEL, P.; TAVARES, R.; PISA, P. S.; ARAUJO, R. M.

Bridging the Gap between Brazilian Startups and Business Processes - Process Thinking's Initial Exploratory Case Study

isys | Revista Brasileira de Sistemas de Informação, Rio de Janeiro, vol. 10, No. 1, pp. 19-38, 2017
} 
The diagnosis was collaborative constructed through these meetings and the SWOT matrix (Figure 6) indicated some weaknesses (W2, W5, W6, W7, and W8) that could be addressed through the improvement of the proper processes.

Regarding scope step, the respective processes were then selected from Process Thinking map: Services - Services Execution (Develop Commercial Proposal, Allocate Human Resources, and Track Projects (Figure 7)). In the following AS-IS step, the current practices related to the selected processes were elicited and registered on a process summary (Figure 8), where some missing parts (not implemented yet) were highlighted in red. In the TO-BE step, the business processes selected were extracted from Process Thinking process map and then adapted to We Sense context considering its previous documents, activities, terms, actors, and practices, as can be seen in the process presented in Figure 9. Finally, the Implementation step was responsible for making the use of the new processes real in We Sense daily activities. During this step, from the utility belt, new spreadsheets and documents were provided to support some specific activities in the process. For instance, considering the difficulties with the establishment of contracts some standard models have been proposed. In addition, to assist in the implementation of the new rules of pricing, a spreadsheet with all the variables required for calculations was suggested.

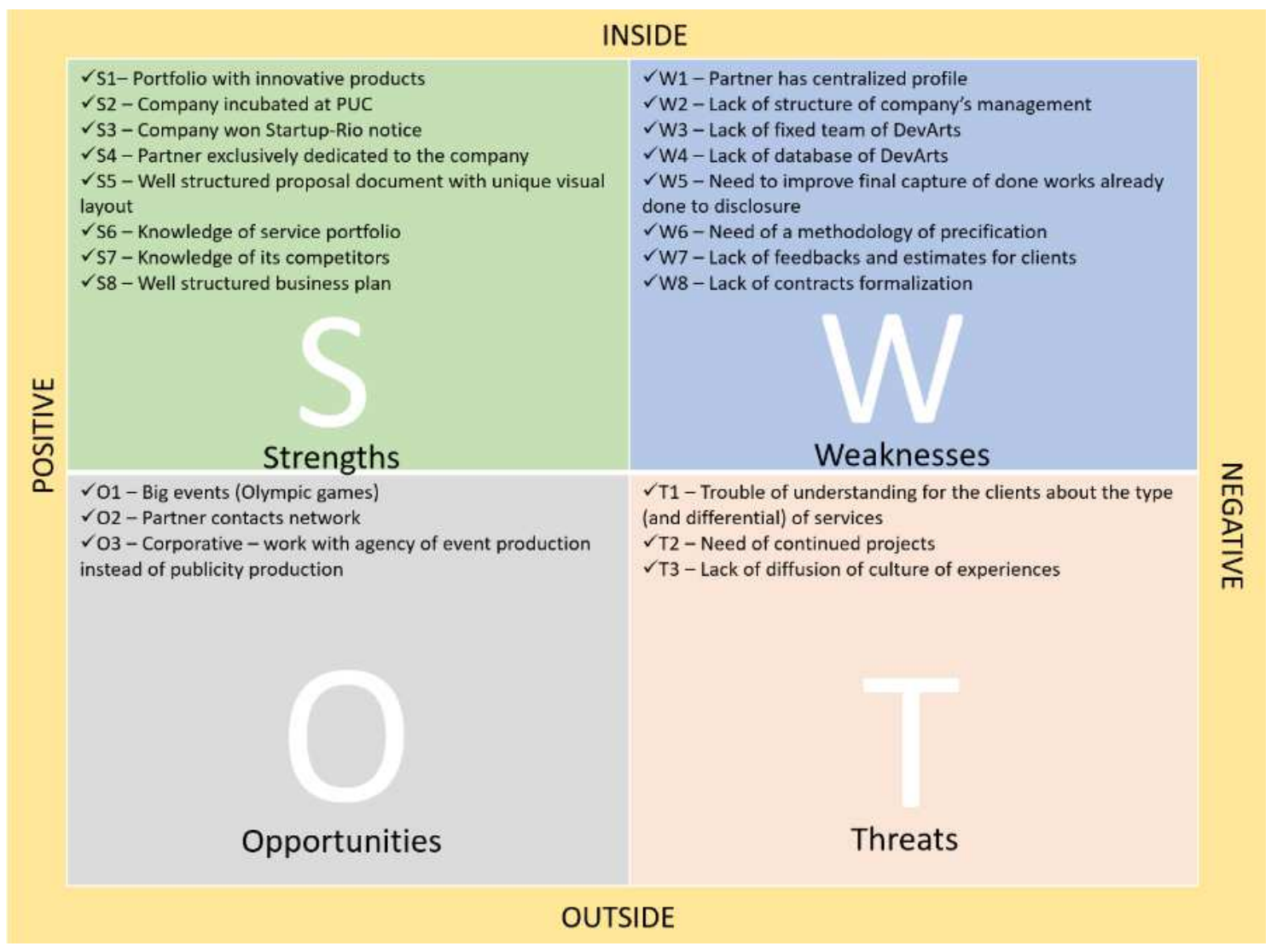

Figure 6 - SWOT matrix

MAGDALENO, A. M.; ENGIEL, P.; TAVARES, R.; PISA, P. S.; ARAUJO, R. M.

Bridging the Gap between Brazilian Startups and Business Processes - Process Thinking's Initial Exploratory Case Study

isys | Revista Brasileira de Sistemas de Informação, Rio de Janeiro, vol. 10, No. 1, pp. 19-38, 2017 


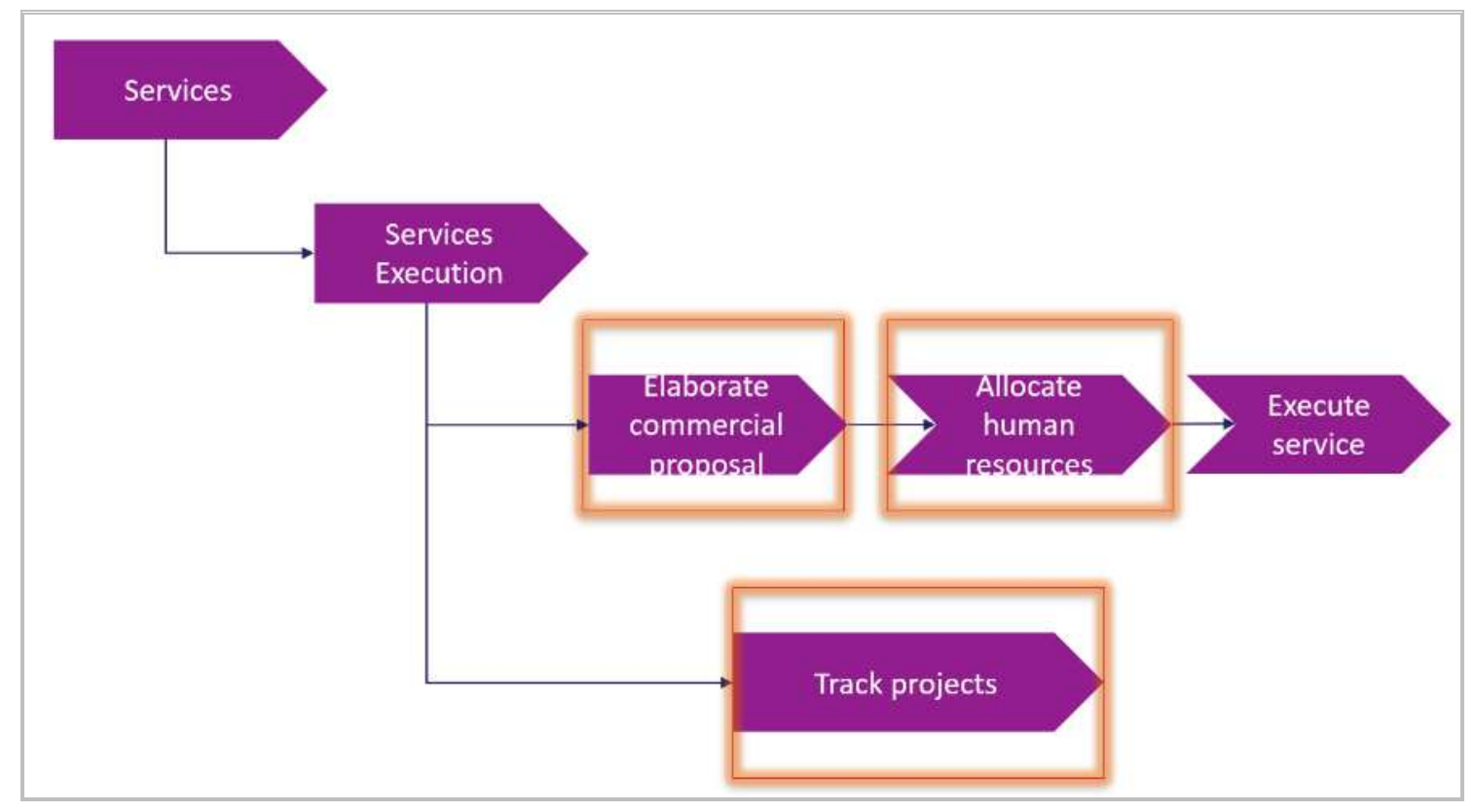

Figure 7 - Selected processes

Process

Elaborate commercial proposal

Objectives:

$\checkmark$ Estimate cost and deadline of the project

$\checkmark$ Present commercial proposal to client

\begin{tabular}{|lcl}
\hline Main Activities: & $\checkmark$ Calculate company costs (sales & $\checkmark$ Elaborate client contract \\
$\checkmark$ Understand demand & commission, project risk and & $\checkmark$ Sign contract with client \\
$\checkmark$ Calculate equipment costs & profit margin) \\
$\checkmark$ Request collabs quotation & $\checkmark$ Elaborate simplified commercial \\
$\checkmark$ Calculate team costs & proposal \\
$\checkmark$ Calculate costs with services (travel, & $\checkmark$ Negotiate commercial proposal \\
freight, emergency rate) & $\checkmark$ Elaborate commercial proposal \\
\end{tabular}

\begin{tabular}{|l|l|}
\hline $\begin{array}{l}\text { Inputs/Suppliers: } \\
\checkmark \text { Adegraf table }\end{array}$ & $\begin{array}{l}\text { Products/Clients: } \\
\checkmark \text { Estimate spreadsheet (commercial director) } \\
\checkmark \text { Commercial proposal (client) } \\
\checkmark \text { Simplified commercial proposal (client) } \\
\checkmark \text { Contract (client) }\end{array}$ \\
\hline
\end{tabular}

\footnotetext{
Systems/Tools:

$\checkmark$ Excel

$\checkmark$ Word
}

Figure 8 - Process summary (with the missing parts in red)

MAGDALENO, A. M.; ENGIEL, P.; TAVARES, R.; PISA, P. S.; ARAUJO, R. M.

Bridging the Gap between Brazilian Startups and Business Processes - Process Thinking's Initial Exploratory Case Study

isys | Revista Brasileira de Sistemas de Informação, Rio de Janeiro, vol. 10, No. 1, pp. 19-38, 2017 


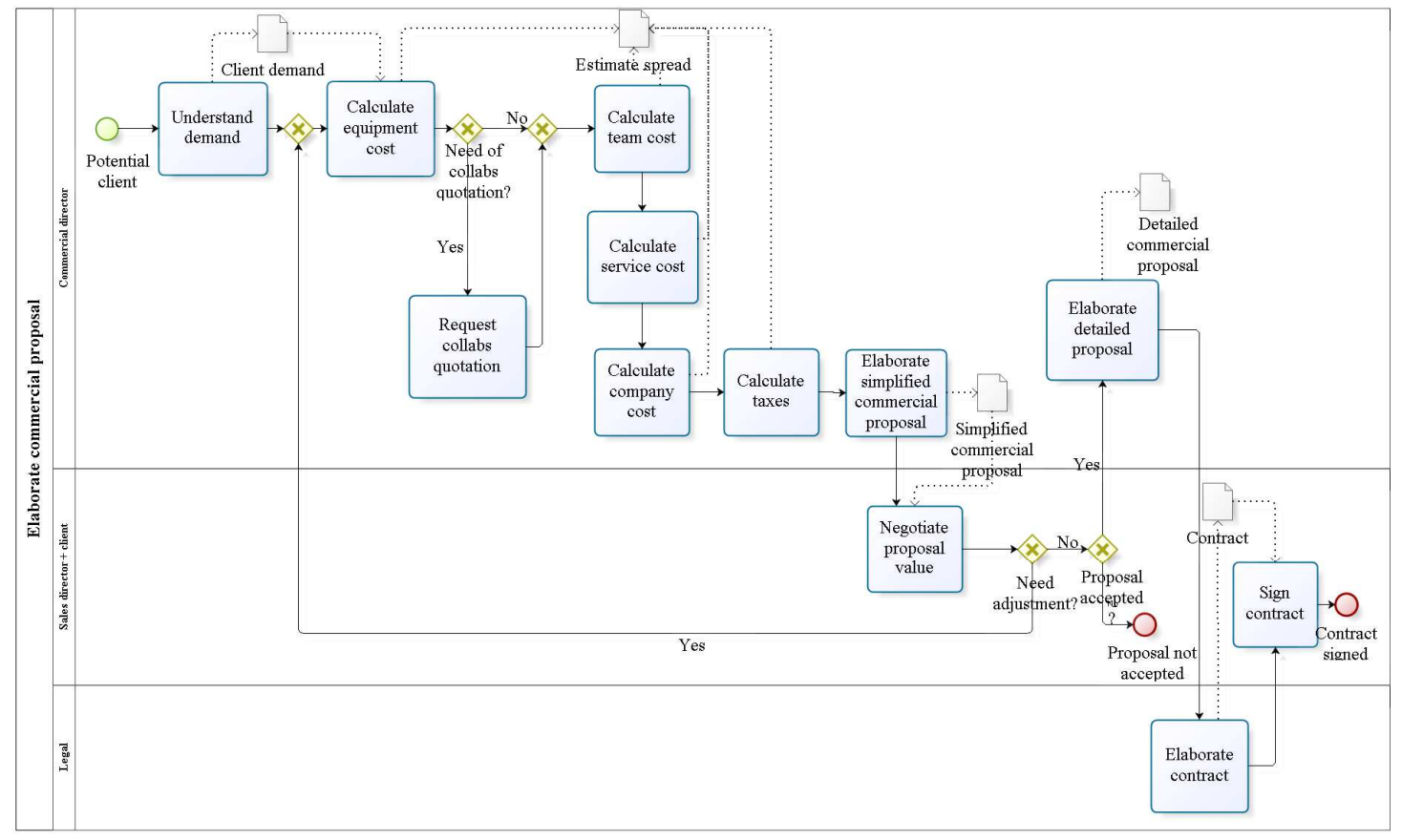

Figure 9 - TO-BE Process

\subsection{Results Analysis and Discussions}

Motivated, interested, and dedicated to the success of his startup, the entrepreneur quickly assimilate all the proposed improvements and implemented them even during the execution of the study, applying them in his ongoing projects. For instance, the company pricing method was completely reviewed to include parameters such as lodging, equipment freight, company fixed expenses, and profit margin. The new spreadsheet was immediately applied on new requests and on the ongoing negotiations. Similarly, the new contract's models and business proposal's template were put into practice.

Thus, the results beginning to be observed almost immediately, through the adoption of the proposed processes and artifacts. The initial calculations indicated that the entrepreneur was receiving 50\% less in his projects than he ought to be, because he was not able to analyze all the variables involved in his pricing and not to know some market practices. This practical experience indicated the great potential of Process Thinking to make a positive impact in the short and medium term strategies and management of startups companies.

The study also indicates, as a first evidence, that the process map and the utility belt are adequate for startups. In this study, we evaluated only 3 processes and their artifacts, but it was possible to instantiate all of them for the We Sense reality with templates and documents that helped in the daily routine.

The qualitative feedback received is summarized as follows: "The service is those that we have no idea that we need, but during the consulting, I asked me a few times, as I did not know that before! I feel much more prepared since. In fact, what they achieved was to create methods based on my expertise, which help me to have a holistic

MAgDALENO, A. M.; ENGIEL, P.; TAVARES, R.; PISA, P. S.; ARAUJO, R. M.

Bridging the Gap between Brazilian Startups and Business Processes - Process Thinking's Initial Exploratory Case Study

isys | Revista Brasileira de Sistemas de Informação, Rio de Janeiro, vol. 10, No. 1, pp. 19-38, 2017 
view of the main points of We Sense. Now we can create a solid base to get to the next steps in a guided way in needs and expectations that are entitled to the living moment".

We also observed that before the contact with Process Thinking, the entrepreneur was only focused on services delivery. With the Process Thinking, he started to think about the support processes and to better organize the company management.

This exploratory study was also helpful to indicate an opportunity of improvement in Process Thinking: during the study we adopted BPMN (Business Process Management Notation) [OMG, 2009], a traditional BPM language for process modeling. However, during the meetings with the entrepreneur we realized that this notation could be complex for non-familiar users. It means that they would have to be trained to understand the processes represented in BPMN notation. It can be time and money consuming, and becoming not productive. Therefore, the entrepreneur indicated the need of a simplified representation, which he can share with future team members.

Finally, this study also demonstrates that Process Thinking methodology is not so simply to apply. It is necessary some work hours of specialists. Therefore, it may not be so adequate to small startups that do not have a specific budget to consulting hire. Then, it is necessary to have a way to apply the process map and the utility belt without the presence of specialists.

\subsection{Threats to Validity}

This section discusses the main limitations of this exploratory case study, including the threats to validity, classified according to [Wohlin et al., 1999].

The main threat to conclusion validity is the size of sample - number of companies and subjects involved. First, this exploratory study used data from a single startup. Second, the size of population is reduced, with only one subject. Therefore, it is not possible to apply a statistical or quantitative analysis. In addition, we evaluated only 3 processes and their artifacts. Therefore, this study presents a limitation in the results that will be considered only as initial evidence, since they cannot be generalized. On the other hand, qualitative feedback was provided and helped in the interpretation of the results.

Obviously, performing an analysis with a larger number of companies would be important to gather more insights about the suitability of the Process Thinking to startups in general. Nevertheless, finding real and interesting instances is not a simple task. Processes tend to be strategic for most companies and they usually do not allow a research to collect the required data. Besides, this data tends to lack a proper structure and to require significant effort to be collected and organized.

\section{Related Work}

One first alternative to improve the traditional BPM approaches to deliver results and products as expected is to adapt the agile practices of software development - like Scrum [Schwaber, 2004] or Extreme Programing (XP) [Beck, 2004] - to BPM. It would make this approach more dynamic and iterative, delivering early products and achieving

MAGDALENO, A. M.; ENGIEL, P.; TAVARES, R.; PISA, P. S.; ARAUJO, R. M.

Bridging the Gap between Brazilian Startups and Business Processes - Process Thinking's Initial Exploratory Case Study

isys | Revista Brasileira de Sistemas de Informação, Rio de Janeiro, vol. 10, No. 1, pp. 19-38, 2017 
customer's satisfaction. With this in mind, emerged the idea of Agile BPM [Magdaleno, 2014a; Magdaleno, 2014b; Thiemich and Puhlmann, 2013]. However, this approach is not specifically focused on startups.

Some initiatives to approximate BPM to startups context already exist. One example is Method $\mathrm{Kit}^{10}$, which provides a checklist with the topics that they consider important for a company to analyze in form of a set of cards. Each card has a topic, an icon, and a little description. The cards were projected to help the brainstorming of a work group aiming to achieving a general vision of the business. They have different themes including personal life or web development. This kit was purchased and tested by our team and we can say that it is a different product from Process Thinking because it is general and not focused on processes.

The Business Model Design Toolkit (BMG Toolkit) ${ }^{11}$ helps a team to develop their business model and value proposition. For the business model they propose the use of canvas [Osterwalder and Pigneur, 2011] - an strategic management tool that helps to develop and describe new or existent business models; and for the value proposition they indicate to think what your company offers the customer to reduce their problems and increase your earnings performing the daily tasks. This approach focus on the business model and not in process and activities that need to be done.

Lean Startup [Ries, 2011] propose a new way to think and built innovate products and services. The core component of the approach is a feedback loop. After discovering what problem needs to be solved, the idea is to develop a minimum viable product (MVP) to have a feedback as soon as possible. This approach does not focus on startups' processes. It is concerned about the development of the product and not the startup management.

Specifically focusing on processes, the work of [Anderson, 2013] claims that in any organization there exists a common set of core business processes for an organization to function properly. Small organizations start with a reduced set of core processes and then grow. Growth introduces new complexities that require more employees and more focus. The core processes are: Customer Strategy \& Relationships (Marketing); Employee Development \& Satisfaction; Quality, Process Improvement \& Change Management; Financial Analysis, Reporting, \& Capital Management; Management Responsibility; Customer Acquisition (Sales); Product Development; Product/Service Delivery; Accounting Management; and Technology Management.

Maschka [2014] did a survey in small companies and with BPM experts to investigate the use of BPM in Brazil micro and small companies. The survey data generate a set of micro and small companies' characteristics that contribute to BPM implementation.

Analyzing the related works previously presented, we can observe a lack of empirical research about BPM and startups. Therefore, we expanded our search for

\footnotetext{
${ }^{10}$ Method Kit: http://www.methodkit.com

${ }^{11}$ BMG Toolkit: http://www.stattys.com/bmg-toolkit.html

MAGDALENO, A. M.; ENGIEL, P.; TAVARES, R.; PISA, P. S.; ARAUJO, R. M.

Bridging the Gap between Brazilian Startups and Business Processes - Process Thinking's Initial Exploratory Case Study

iSys | Revista Brasileira de Sistemas de Informação, Rio de Janeiro, vol. 10, No. 1, pp. 19-38, 2017
} 
software processes and startups. Basically, the works identified in this field are dedicated to bibliography revisions about startup software development [Crowne, 2002; Fayad et al., 2000; Giardino et al., 2014; Paternoster et al., 2014]. Although some of them are not directly related to BPM, they also contribute to startups context understanding and to Process Thinking main processes definition, especially regarding to Products development.

Crowne [2002] tries to analyze why some software product startups fail and to provide some ideas to help. The main causes are: inexperience of developers, product isn't really a product, no strategic plan for product development, requirements become unmanageable, and product expectation is too high. One can observe that some causes mentioned can be mitigated using BPM to organize the software process and to align it with company' strategy.

Paternoster et al. [2014] conducted a mapping study to provide a panorama of the state of art in software startup research. The conclusion is that the body of knowledge is limited to a few studies and the software engineering practices in this kind of organizations are chosen opportunistically.

Giardino et al. [2014] also performed an investigation about software engineering sources related to startups and their engineering practices. High uncertainty and rapid evolution are the two key characteristics for startups retrieved by the studies. They concluded that engineering activities must be adapted to startup context.

Fayad et al. [2000] discuss significant development issues that have not been adequately addressed in software engineering literature: company size, development mode, development size, and development speed. This characterization is important to arise in a solution to software engineering for small companies.

\section{Conclusion}

This paper presented Process Thinking framework to support startups in the analysis and rethinking of their main business processes in a playful, agile and innovative way. Process Thinking comprises a process map with 10 main processes, the process flow for each of them, and a utility belt with document templates, examples, tools, and references to help process execution.

Process Thinking was applied in a first exploratory case study with a young IT startup. The study applied a 5-step methodology during 2 months of work with the startup owner. The results indicate a positive impact in the short and medium term strategies and management of the startup. The study also highlighted that BPMN can be complex for non-technical users, which miss a simplified representation to improve processes comprehension.

Our research agenda on this topic is plenty of opportunities. First, there is the possibility of complementing the Process Thinking framework with other techniques during startups use. The management of a company has different dimensions and processes are just one of them. Organizational strategy or hierarchy can also contribute with insightful ideas. Although this idea is out of scope of this work, it can also be investigated on future researches.

MAGDALENO, A. M.; ENGIEL, P.; TAVARES, R.; PISA, P. S.; ARAUJO, R. M.

Bridging the Gap between Brazilian Startups and Business Processes - Process Thinking's Initial Exploratory Case Study

isys | Revista Brasileira de Sistemas de Informação, Rio de Janeiro, vol. 10, No. 1, pp. 19-38, 2017 
Considering We Sense exploratory case study feedback about process languages comprehension, we can analyze the opportunities for business process language simplification. Based on a previous work [Engiel et al., 2014], which defines a catalogue of characteristics of understanding in process models, one can propose a Process Thinking Representation Language (PTRL) that aims to be simpler, easier to learn and to explain. It can be based on workflow, have small number of elements and use ludic symbols. The ability to make a process more understandable is important when we are trying to reduce the time spent by startup people to learn the notation before they start to think about their processes. Besides, modeling tool can be developed to support the use of PTRL.

Second, we intend to continue the evaluation plan. One possibility is to conduct a peer review with process specialists in Marketing, Human Resources etc. to gather new ideas and suggestions to Process Thinking map. In addition, future studies can amplify the sample of Process Thinking experimental studies in terms of number and types of companies and subjects involved. Process Thinking sponsors are small startups that can be a potential application scenario.

Considering process map and utility belt use in startups, one should also consider that they were not proposed to be used as a strait jacket. Entrepreneurs should adapt and evolve them according to their needs. For instance, define their own processes from the process map if the model proposed is not suited to their context. The utility belt can be constantly evolving with the addition of new tips. Therefore, opportunities for customization can also be explored in future evaluations.

Another future work is the creation of a deck of cards that help the rethinking of processes by entrepreneurs themselves without the help of a consulting team. Each process can be represented by a card with an icon, name and main topics. Each card raises typical questions of general processes of a startup, and entrepreneurs can exercise the reasoning of process improvement on their own. It can also be a business opportunity as a more scalable model for the adoption of the Process Thinking.

If the idea presented above works with generic processes, on the other hand, we can also think about how to deal with the specifics (team size, business sector, etc.) of different types of startups. One way to develop this opportunity is to deal with processes variations, such as in process lines [Barreto et al., 2011; Magdaleno et al., 2012; Martínez-Ruiz et al., 2009; Montero et al., 2007; Nunes et al., 2010; Puhlmann et al.], which allows creating a generic (set of) process(es) that capture(s) the commonalities and controlled variabilities across a domain [Rombach, 2006]. Process lines prepare the processes to suit future anticipated (process) needs by determining a common process core and variable process parts that satisfy specific needs.

Finally, another interesting topic that deserves attention in future research is the creation of a workshop that teaches the main concepts of process management for entrepreneurs. In a dynamic environment, it promotes discussion and collaboration among participants on analysis and improvement of common processes between them. With the instructor acting as a facilitator and raising the typical challenges of each of these processes, the assembled entrepreneurs can share tips, best practices, make suggestions, and learn from the experiences presented.

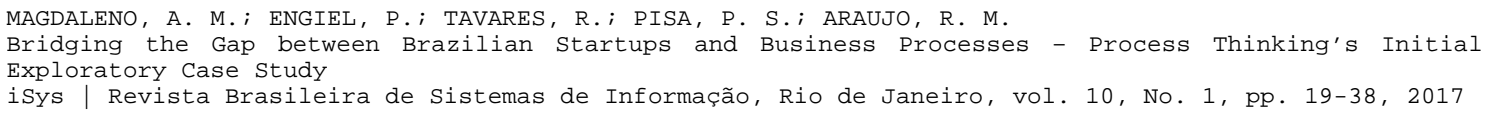




\section{Acknowledgments}

This research was partially funded by Inova Talentos from IEL/CNPq. We are grateful to the disclosure agreement given by We Sense (http://www.wesense.com.br) for this publication. The authors also would like to thank Process Thinking sponsors: Dheka (http://www.dheka.com.br), Innolevels (http://www.innolevels.com.br) and Kendoo (http://www.kendoo.com.br). Rafael Lage Tavares also would like to thank CNPq for providing research grant for this project (SET-F mode, number 351294/2015-5).

\section{References}

Anderson, C. (2013). "What Are the Top Ten Core Business Processes?". Bizmanualz, Available at: https://www.bizmanualz.com/improve-business-processes/what-are-thetop-ten-core-business-processes.html.

Baldam, R. et al. (2009). "Gerenciamento de Processos de Negócio". São Paulo, SP, Brasil: Érica (In Portuguese).

Barreto, A. S. et al. (2011). "Software Process Definition: a Reuse-based Approach". Journal of Universal Computer Science (JUCS), v. 17, n. 13, pp. 1765-1799.

Basili, V. R. et al. (1994). "The goal question metric approach". Encyclopedia of software engineering, v. 1, pp. 528-532.

Beck, K. (2004). "Extreme Programming Explained: Embrace Change". Boston, MA, USA: Addison-Wesley.

Blank, S., and Dorf, B. (2014). "The Startup Owner's Manual: The Step-by-Step Guide for Building a Great Company". K\&S Ranch.

Crowne, M. (2002). "Why software product startups fail and what to do about it. Evolution of software product development in startup companies". In: IEEE International Engineering Management Conference (IEMC), Cambridge UK, pp. 338343.

Damodaran, A. (2012). "Investment Valuation: Tools and Techniques for Determining the Value of any Asset, University Edition". Hoboken, New Jersey: Wiley.

Dumas, M. et al. (2013). "Fundamentals of Business Process Management". New York: Springer.

Elzinga, D. J. et al. (1995). "Business process management: survey and methodology". Engineering Management, IEEE Transactions on, v. 42, n. 2, pp. 119-128.

Engiel, P. (2014). "As 6 fases do ciclo de BPM”. Blog dheka (In Portuguese), Available at: http://www.dheka.com.br/6-fases-ciclo-gestao-processos-negocio.

Engiel, P. et al. (2014). "Designing Public Service Process Models for Understandability". The Electronic Journal of e-Government (EJEG), v. 12, n. 1, p. 95-111.

Fayad, M. E. et al. (2000). "Thinking Objectively: Software Engineering in the Small". Commun. ACM, v. 43, n. 3, pp. 115-118. 
Giardino, C. et al. (2014). "What Do We Know about Software Development in Startups?". IEEE Software, v. 31, n. 5, pp. 28-32.

Magdaleno, A. M. et al. (2012). "COMPOOTIM: An Approach to Software Processes Composition and Optimization". In: Congresso Ibero-Americano em Engenharia de Software (CIbSE), Buenos Aires, Argentina, pp. 1-14.

Magdaleno, A. M. (2014a). "BPM Ágil: adaptando valores, princípios e práticas do desenvolvimento ágil para BPM". Dheka Blog (In Portuguese), Available at: $\mathrm{http}$ ://dheka.com.br/bpm-agil-adaptando-valores-principios-praticas-desenvolvimentoagil-para-bpm.

Magdaleno, A. M. (2014b). "BPM Ágil: Como inserir práticas ágeis no ciclo de BPM?". Dheka Blog (In Portuguese), Available at: http://dheka.com.br/abordagem-de-bpm-agilcomo-inserir-praticas-ageis-ciclo-de-bpm.

Martínez-Ruiz, T. et al. (2009). "Process Institutionalization using Software Process Lines". In: ICEIS, , pp. 359-362.

Maschka, M. G. (2014, September). "Gestão de Processos de Negócios: Um Estudo Empírico em Micro e Pequenas Empresas Brasileiras". Recife - PE: Universidade Federal de Pernambuco.

Montero, I. et al. (2007). "Business Family Engineering: Does it make sense?". I JISBD Taller sobre Procesos de Negocio e Ingenieria del Software (PNIS), Zaragoza, España, pp. 34-40.

Nunes, V. T. et al. (2010). "Context-Based Process Line". International Conference on Enterprise Information Systems (ICEIS), Funchal, Madeira, Portugal, pp. 277-282.

OMG. (2009). "Business Process Management Notation (BPMN) Version 1.2". http://www.bpmn.org/.

Osterwalder, A., and Pigneur, Y. (2011). "Business Model Generation. Inovação Em Modelos De Negócios". Rio de Janeiro: Alta Books.

Paim, R. (2009). "Gestão de processos: pensar, agir e aprender". Porto Alegre: Bookman (In Portuguese).

Paternoster, N. et al. (2014). "Software development in startup companies: A systematic mapping study". Information and Software Technology, v. 56, n. 10, pp. 1200-1218.

Puhlmann, F. et al. "Variability Mechanisms for Process Models". .

Ries, E. (2011). "The Lean Startup: How Today's Entrepreneurs Use Continuous Innovation to Create Radically Successful Businesses". New York: Crown Business.

Rombach, D. (2006). "Integrated Software Process and Product Lines". Unifying the Software Process Spectrum, Heidelberg: Springer-Verlag, pp. 83-90.

Schwaber, K. (2004). "Agile Project Management with Scrum". Washington, DC, USA: Microsoft Press.

MAGDALENO, A. M.; ENGIEL, P.; TAVARES, R.; PISA, P. S.; ARAUJO, R. M.

Bridging the Gap between Brazilian Startups and Business Processes - Process Thinking's Initial Exploratory Case Study

isys | Revista Brasileira de Sistemas de Informação, Rio de Janeiro, vol. 10, No. 1, pp. 19-38, 2017 
SEBRAE-MG. (2014). "O que é uma empresa startup?". SEBRAE MG: Biblioteca Digital, https://www.sebraemg.com.br/atendimento/bibliotecadigital/documento/texto/oque-e-uma-empresa-startup.

Sharp, A., and McDermott, P. (2001). "Workflow Modeling: Tools for Process Improvement and Application Development". Artech House Publishers.

Stickdorn, M., and Schneider, J. (2012). "This Is Service Design Thinking: Basics, Tools, Cases". Hoboken, New Jersey: Wiley.

Thiemich, C., and Puhlmann, F. (2013). "An Agile BPM Project Methodology". F. Daniel et al. (Eds.), Business Process Management, Lecture Notes in Computer Science.Springer Berlin Heidelberg, pp. 291-306.

Weibach, R. et al. (2016). "Challenges in Business Process Modeling - Is Agile BPM a solution?". In: Workshop on Social and Human Aspects of Business Process Management (BPMS2), Rio de Janeiro, RJ, Brasil.

Weske, M. (2012). "Business Process Management: Concepts, Languages, Architectures". Heidelberg; New York: Springer.

Wohlin, C. et al. (1999). "Experimentation in Software Engineering: An Introduction". Springer. 